\title{
Correction to: EFL College Students' Concordancing for Error Correction
}

探討大學生使用語料檢索之成效及想法

Ying-Hsueh Cheng ${ }^{1}$

(c) National Taiwan Normal University 2021

\section{Correction to: English Teaching \& Learning https://doi.org/10.1007/s42321-021-00075-5}

The article was originally published without pertinent data in Table 7 . The original article has been updated.

The original article can be found online at https://doi.org/10.1007/s42321-021-00075-5.

Ying-Hsueh Cheng

folyhc@ccu.edu.tw

1 Department of Foreign Languages and Literature, National Chung Cheng University, No.168, Sec. 1, University Rd.Min-hsiung, Chia-yi 62102, Taiwan 